\title{
BUILDING STRONGER STATE ENERGY PARTNERSHIPS WITH THE U.S. DEPARTMENT OF ENERGY
}

\section{Final Technical Report}

Reporting Period State Date: July 16, 2000

Reporting Period End Date: July 16, 2008

Submitted by

David Terry

Issued January 2009

DOE Award Number DE-FC26-00NT40802

Submitting Organization:

National Association of State Energy Officials (NASEO)

1414 Prince Street, Suite 200

Alexandria, VA 22314 


\section{Disclaimer}

This report was prepared as an account of work sponsored by an agency of the United States Government. Neither the United States Government nor any agency thereof, nor any of their employees, makes any warranty, express or implied, or assumes any legal liability or responsibility for the accuracy, completeness, or usefulness of any information, apparatus, product, or process disclosed, or represents that its use would not infringe privately owned rights. Reference herein to any specific commercial product, process, or service by trade name, trademark, manufacturer, or otherwise does not necessarily constitute or imply its endorsement, recommendation, or favoring by the United States Government or any agency thereof. The views and opinions of authors expressed herein do not necessarily state or reflect those of the United States Government or any agency thereof. 


\begin{abstract}
This final technical report details the results of total work efforts and progress made from July 2000 - July 2008 under the National Association of State Energy Officials (NASEO) cooperative agreement DE-FC26-00NT40802, Building Stronger State Energy Partnerships with the U.S. Department of Energy. Major topical project areas in this final report include work efforts in the following areas: Rebuild America/Energy Smart Schools, Higher Education Initiative, Winter/Summer Fuels Outlook Conferences, Energy Emergency, Clean Energy Integration, Energy Star, and Office of Electricity Delivery and Energy Reliability. All required deliverables have been provided to the National Energy Technology Laboratory and DOE program officials.
\end{abstract}




\section{TABLE OF CONTENTS}

Subject Area

EXECUTIVE SUMMARY

EXPERIMENTAL METHODS

RESULTS AND DISCUSSION

- Rebuild America/Energy Smart Schools

- Higher Education Initiative

- Winter/Summer Fuels Outlook Conferences

- Energy Emergency

- Clean Energy Integration

- Energy Star

- Office of Electricity Delivery and Energy Reliability
$\underline{P a g e(s)}$

1

2

$3-7$

$7-8$

8

$8-10$

11-12

12-13

13

14

CONCLUSION 


\section{EXECUTIVE SUMMARY}

The Department of Energy/National Association of State Energy Officials cooperative agreement, "Building Stronger State Energy Partnerships with the U.S. Department of Energy" was in place during the years 2000 through 2008. All tasks and objectives, as well as task deliverables, have been accomplished and delivered as set forth in the agreement.

NASEO and its partners have been able to successfully provide coordination, outreach, education, training, analysis, and technical assistance to States and Territories in the major task areas of the cooperative agreement.

- Rebuild America/Energy Smart Schools

- Higher Education Energy Efficiency

- Winter/Summer Fuels Outlook Conferences

- Energy Emergency

- Clean Energy Integration

- Energy Star and

- Office of Electricity Delivery and Energy Reliability

Through its unique membership (state and territory energy officials from around the country) and collaborative relationship with other state, national, and private energyfocused organizations, NASEO was able to work with the states to identify areas of needed assistance, and opportunities for DOE/state partnerships efforts. 


\section{EXPERIMENTAL METHODS}

No experimental methods, materials, or equipment were used during the reporting period. 


\section{RESULTS AND DISCUSSION}

The award for this project work, Building Stronger State Energy Partnerships with the U.S. Department of Energy, was made in July 2000. The original work plan was focused on the Rebuild America Program (RBA) and was geared toward addressing some project development and communications barriers between the State Energy Offices (SEOs) and the RBA program. Over the next eight years, additional work activities were funded by the Office of Energy Efficiency and Renewable Energy as well as the Office of Electricity Delivery and Energy Reliability under the cooperative agreement. This final technical report covers all work, reported by major topical areas, funded under award DE-FC26-00NT40802 from July 2000 through July 2008. Major topical project areas in this final report include work efforts in the following areas:

Rebuild America/Energy Smart Schools, Higher Education Initiative, Winter/Summer Fuels Outlook Conferences, Energy Emergency, Clean Energy Integration, Energy Star, and Office of Electricity Delivery and Energy Reliability. All required deliverables have been provided to the National Energy Technology Laboratory and DOE program officials.

\section{REBUILD AMERICA}

In late 2000, the Rebuild America Program was having difficulty in assisting states in forming partnerships with communities and taking advantage of the RBA's technical assistance and other resources. NASEO's efforts, over a four-year period, were aimed at educating state energy offices about available RBA resources and delivering key information and state success stories in order to accelerate the spread of the RBA program. NASEO also focused on identifying state concerns and problems in implementing RBA activities. NASEO completed all activities under the two Rebuild America tasks.

\section{Task 1 - Rebuild America Outreach}

NASEO and its Building Committee would focus on raising awareness and coordination of Rebuild America activities. NASEO staff and the committee will assist Rebuild officials in stimulating interest in the program and building greater support among SEO Directors through the following four subtasks:

Subtask $1 A-$ Assist Rebuild in communicating with SEO Directors regarding SEP Special Projects and NASEO web site

Subtask 1B - Prepare three articles for NASEO's news page

Subtask C - Provide feedback and ongoing communication with SEO Directors for each NASEO region and the Buildings Committee

Subtask D - Participate in coordination efforts among key Rebuild stakeholders in Washington, DC.

Accomplishments for subtasks 1A through 1D include:

- Developed and delivered, through its Buildings Committee members, one-on-one communications with State Energy Directors and presentations and information 
materials at regional and national meetings. Developed a state-based package of educational materials on Rebuild America successes and program information.

- Collected RBA state success stories and provided this information to RBA consultants for use in web site development.

- Completed the "State and Territory Energy Office Model Approaches to Rebuild America" document. The approaches were provided by the states of Colorado, Utah, Arkansas, California, Illinois, and New York and serve as models that other states might adopt or adapt in order to expand the reach of their Rebuild America partnerships and expedite delivery of energy savings.

- Added links to its Buildings Committee web site location for both Rebuild America and State Rebuild pages to increase communications and information exchange.; developed a list serve electronic communications service to distribute the latest Rebuild information; and held monthly regional conference calls.

- Through its website, regular conference calls, and emails, NASEO insured that SEO Directors understood the opportunities available for Rebuild America projects through the SEP Special Projects.

- Collected sample Rebuild data from various states to serve as samples of the type of Rebuild data needed as well as templates for displaying the data. This information was provided to State Energy Offices and RBA staff.

- Finalized the draft of the Public Buildings Manual which aided the states and Rebuild in the delivery of technical assistance by identifying state needs and connecting those states with Rebuild resources.

- Hosted five Rebuild America Business Partner lunches at the 2003 Energy Outlook Conference. Each participating business partner gave a 1.5 hour presentation with question and answer period. The five business partner presenters represented: Siemens, Trane Company, Westinghouse Lighting Corporation, U.S. EPA Energy Star, and The Stella Group.

During 2001-2002, Subtasks $1 \mathrm{E}$ and $1 \mathrm{~F}$ were added to Task 1. Subtask $1 E$ - Integrated Energy and Environmental Initiatives

Support for state plans to implement integrated energy and environmental initiatives, including distributed generation technologies

NASEO began work on Subtask $1 \mathrm{E}$ in September 02 by conducting coordination meetings with various state, DOE, and environmental agencies to determine how best to provide assistance to states and which states to target. Initial regional energy, environment, and transportation coordination meetings were organized in the States of Pennsylvania and Mississippi. NASEO also conducted meetings with the National Association of Regulatory Utility Commissioners to discuss cooperative activities on clean distributed generation applications and state energy/environmental needs. Finally, NASEO staff arranged for the Massachusetts Energy Office to make a technical presentation on its DG/emissions tracking system to all of the State Energy Offices at a meeting in February 2003.

The Mid-Atlantic Sustainability Conference, which was held June 4-7, 2003 which was attended and promoted to the SEOs by NASEO, provided information about the most important trends in environmental business, energy, buildings, public policy, and landuse planning. 
The "Creating Energy-Air Quality Collaboratives in the Northeast and Mid-Atlantic States" conference, co-hosted by the Ozone Transport Commission, the National Association of Regulatory Utility Commissioners, and NASEO, was held October 22-23, 2002 in Westbrook, Connecticut. The conference built upon the highly successful national and regional meetings to date on integrating the approaches of energy, environment, and public utilities. The main theme was to emphasize how to develop successful state projects and public/private partnerships that capitalize on the joint involvement and innovation of state air quality, energy, and public utility commission representatives.

NASEO utilized information gathered from all the above meetings, presentations, and conferences to keep the State Energy Offices up-to-date on the latest energy, environment, and transportation planning, projects, and share state success stories of integrated energy/environment projects. Communication efforts included the NASEO web site, NASEO newsletter, regional conference calls, and on-site meetings with state energy officials.

\section{Subtask $1 F$ - Turbine Collaborative Initiative}

Initiation of a state collaborative on advanced turbines and hybrid systems. - Assist Western states to identify collaborative research, development, demonstration, and deployment opportunities for advanced gas turbines and hybrid systems.

Work on this task began in September 2001 with telephone and in-person meetings between NETL program staff, consultants, and NASEO. At the October 2001 NASEO Annual Meeting, the initiative was introduced and Western State Energy Offices and others were invited to provide input and indicate their interest on the project. Based on the high level of interest expressed by the SEOs, NASEO moved forward to plan and implement three turbine workshops in Portland, Oregon; Golden, Colorado; and Palo Alto, California. The workshops involved officials from surrounding states and turbine experts in focused half-day sessions to discuss the turbine initiative project. Panels of field experts presented information on turbine-related issues, needs, and opportunities. Following are the results of the three turbine workshops:

1. The Advanced Turbine Opportunities Workshop was held in Portland, Oregon, at the headquarters of the NWPPC on July 22, 2002. The top issue that arose out of this workshop was interconnection standards; the top needs were information and analyses of power quality; the top opportunity was state \& federal utility financial incentives.

2. The second Advanced Turbine Opportunities Workshop was held at the U.S. DOE Denver Regional Office on August 15, 2002. From this workshop, the top issue was: the need for "best engineering" practices"; the top priority was hard data analysis and case studies - education; and the top opportunity arising from the meeting was State Energy Offices' opportunity for collaboration.

3. The Palo Alto Advanced Turbine Opportunities Workshop was held on September 5, 2002, at EPRI. The top issue from this meeting was cost of 
interconnection; the top need was information and information dissemination and credible ( $3^{\text {rd }}$ party) data on emerging technology; the top priority was to relieve transmission bottlenecks.

A final report identifying collaborative state, regional, federal, state government stakeholder research, development, demonstration, and deployment opportunities for advanced gas turbines and hybrid systems was completed and delivered to NETL in 2003.

\section{Task 2 - Rebuild/Energy Smart Schools}

NASEO would work to improve the efficiency of America's schools by assisting states and DOE in promoting projects that result in more energy efficient and clean energy schools and a better learning environment.

- NASEO conducted five Rebuild/Energy Smart Schools decision-maker workshops in Georgia, lowa, Washington, Kentucky, and Mississippi to provide information on Energy Smart Schools and Energy Star Buildings resources. Presentations were provided by leading school energy efficiency program specialists, energy technology providers, and others. Information is provided below on each of the five workshops.

o The Georgia Energy Office and its partners offered public school systems a program that included free energy data analysis and reports, access to technical assistance and participation in energy efficiency demonstration projects. To support this important effort, NASEO, Rebuild America, and other organizations provided assistance for the Greening Georgia Schools event held on March 13, 2001. The meeting included a wide variety of presentations from Georgia energy experts, as well as officials from Rebuild America and NREL. The meeting participants included a diverse mix of school officials, technical staff, design professionals, energy companies, and others.

o lowa's Energy Office conducted a forum that built upon their success in delivering the lowa Energy Bank program to encourage schools to implement new energy saving projects. The meeting was a great success and attendees were engaged in discussions ranging from efficiency financing to geothermal heat pumps to wind energy to new building design.

- Washington, with limited assistance from NASEO and Energy Smart Schools, conducted a session at its School Facilities Conference. The conference focused on assisting school districts in reducing energy consumption and energy costs. The session included information on Energy Smart Schools and Energy Star Buildings resources.

o The Kentucky Energy Office, with support from DOE Rebuild America, Energy Smart Schools, and others, conducted a school decision-maker forum on July 24, 2001, in Erlanger Kentucky. The forum-Energy Smart 
Schools: How to Create and Maintain a Better Learning Environmentincluded presentations from leading school energy efficiency program specialists, energy technology providers, and others.

o The Mississippi Energy Office conducted "Energy Management Workshops for Public School Superintendents and Business Managers" during three half-day sessions between 4/23-25/01 in Granada, Jackson and Hattiesburg, MS. The meetings included presentations on high performance schools (in-house techniques), retrofit of existing buildings, performance contracting, and loan information.

NASEO and DOE Energy Smart Schools officials also hosted four additional similar workshops during the Fall of 2002 in Arizona, Hawaii, North Carolina, and Ohio.

\section{HIGHER EDUCATION INITIATIVE}

NASEO would facilitate project development opportunities with NACUBO, APPA and the states. Work to encourage and assist up to three states in working with Rebuild and NACUBO to identify project partners and assist states and universities in moving ahead on energy efficiency implementation efforts.

By the end of 2001, NASEO through its Buildings Committee and Rebuild officials, identified a need to shift the focus of their Rebuild America/Energy Smart Schools work toward promoting regional coordination, identification of new buildings sector partners (e.g., colleges and universities), and assisting states in strengthening their Rebuild America programs. Working with APPA, the National Association of College \& University Business Officers (NACUBO), and NARUC as well as Rebuild America representatives, NASEO provided information and technical assistance through their State Energy Office partners to assist colleges and universities in increasing energy efficiency. Specific accomplishments include:

- Conducted a data gathering effort in the Fall of 2002 to identify State Energy Office buildings energy efficiency activities within the college and university sector. Responses portrayed activity within the sector by a majority of the SEOs and indicated most SEOs were aware of the available tools and resources from Rebuild America and Energy Star.

- Working with its project partners, NASEO participated in developing fact sheets regarding energy efficiency legislation and technical assistance that would benefit colleges and universities.

- NASEO, with APPA and NACUBO selected Pennsylvania, Ohio, Kentucky and New York as the four states with which to begin the higher education initiative. A process for working with the four identified states was developed with APPA, NACUBO, and NASEO contacting their members in the four states to kick-off the initiative work through a series of conference calls with NASEO members, state Rebuild contacts, and the DOE project manager. It was decided that New York should become a primary model since it had success stories at several universities from which other States could benefit.

- During the 2003 Energy Outlook Conference, NASEO's Buildings Committee distributed the completed State and Territory Energy Office Activity in the College 
and University Sector results report. The results stem from the data gathering effort NASEO undertook in late 2002 to gain a greater knowledge of SEO activity in the college sector. The report was posted on the NASEO web site.

\section{WINTER AND SUMMER FUELS OUTLOOK CONFERENCE}

Since 2003, NASEO has hosted the annual Department of Energy Winter and Summer Fuels Outlook Conferences. The Conferences are sponsored by DOE's Office of Energy Assurance, National Energy Technology Laboratory, and Energy Information Administration. The Conferences, usually held in the Spring and Fall of each year, feature presentations from a range of private-sector and government energy experts with the goal of informing state, federal, local, and other energy officials of the outlook for crude oil, distillate, propane, electricity, and natural gas supplies and prices. The audience includes State Energy Offices, energy industry representatives, government officials, and major media outlets. These Conferences were successfully planned and conducted through Fall 2008. Information on these Conferences is available on the NASEO web site.

\section{ENERGY EMERGENCY}

(1) Strengthen a communications protocol for the States, Territories, and the Federal Government to use to share critical energy supply, demand, and price information in the event of a local, regional, or national energy emergency situation and/or to utilize in order to avoid an emergency situation (2) Support DOE in providing training on the use of geographic information system-based software and/or similar tools, provided by the Federal Government, which assists State and Territory officials in identifying potentially vulnerable energy distribution points and critical energy infrastructure; and (3) Conduct the Summer and Winter Fuels Outlook Conferences held annually in Washington, DC. (NOTE: information provided previously under separate header). Additions made during the first year included (1) Continued updates of EEAC contact lists (2) Coordination with NARUC, NGA, and NCSL (including items such as development of communicative materials and participation in conferences/meetings to garner understanding of and cooperation with EEAC); and (3) Assist five or more States with assessments of their energy assurance, preparedness, and emergency plans. Utilize the energy assurance guidelines to test the plans and train in the development of plans.

Under this task work, which began in 2003, NASEO provided assistance to the States and Territories with energy security training and technical assistance to support coordinated State and Federal energy security and energy emergency planning and training. Specific work activities and accomplishments are detailed below:

\section{Regional Energy Assurance Exercises}

- NASEO, in conjunction with NARUC, held six regional online training workshops for the Energy Emergency Assurance Coordinators (EEAC). Training included: explanation of the purpose and composition of the EEAC; discussion on how and when members should use the system; review of member responsibilities; and demonstration of communication tools (EEAC web site, OEA web site). 
- Planned and participated in various regional energy assurance simulations including Dark Sun Energy Exercise, Dark Mountain, Southeast Energy-Water Interdependence Table Top Exercise (Black Water), Northeast-Mid-Atlantic States Energy Assurance Exercise (Dark Storm).

Energy Assurance Guidelines

- Developed the original draft "State Energy Assurance Guidelines" as a comparison document for current state energy emergency plans; followed by several updates of the Guidelines. The guidelines outlined the states overall role in energy assurance, including organizing and building response mechanisms; coordination with stakeholders; operating within the federal emergency support function structure; planning response strategies; profiling energy use and vulnerability; and identifying fuel-related response measures. As part of its outreach responsibility, NASEO distributed CD copies of the Guidelines to states and other interested parties. The latest Guidelines are available on the NASEO web site.

- Assisted states with assessments of their energy assurance, preparedness, and emergency plans utilizing the NASEO-developed energy assurance guidelines to test the plans and train in plan development.

Development and Monitoring of State Technical Assistance Plans

- Coordinated implementation of three rounds of state technical assistance grants (total of 13 states, Virgin Islands, and District of Columbia), monitored the progress of energy emergency plan development and coordination in participating states, and coordinated submission of the state final reports to DOE. National Association of Regulatory Utility Commissioners 2005-2006

- NARUC, working through its subcontract with NASEO, developed a set of model State policies to improve preparedness of the energy infrastructure to respond to potential catastrophic events including cost recovery models to ensure utilities can better recover prudent costs associated with critical infrastructure upgrades.

- NARUC completed and released the "Model Cost Recovery Protocol for State Public Utility Commissioners." NARUC and the Institute of Public Utilities (IPU) collected essential data on commission practices through two web-based surveys - one on state natural gas curtailment planning and one on state energy assurance planning. NARUC and IPU developed a series of eight reports designed to provide public utility regulators and other participants in the regulatory policy community with introductory overviews, suggested protocols and additional resources on critical infrastructure protection issues.

- Completed two training sessions on Critical Infrastructure Protection providing training for over 50 commissioners and staff representing 16 states. Conducted four "train the trainers" workshops to expand the capacity to train Commissioners on Critical Infrastructure issues. Developed "Training \& Resources" CD and web site.

- Surveyed states' natural gas curtailment policies and compiled data into a database analysis tool for states to use to aid their gas curtailment planning process.

- Conducted and participated in outreach, both to provide information to other groups involved in energy emergencies as well as NARUC staff and 
membership, through various venues: NARUC Winter meetings, DOE-EA's Energy Leadership Forum, NARUC/FERC staff conference, NERC's Cyber Security Standards webcast, INGAA meeting on gas supply shortages, Dark Mountain Energy Assurance Exercise. Northeast Mid-West Institute 2005-2006

- The Northeast Mid-West Institute, working through its NASEO subcontract, provided outreach, education, and communication to policymakers and state stakeholders on the activities of the Division of Infrastructure Security and Energy Restoration in order to promote better awareness and understanding of the Division's role in securing the nation's energy infrastructure, its importance to the states that rely on federal leadership, and its role in providing updates and news that is critical to both preparation and response in the event of energy emergency situations.

- Added information and links to its web site designed to keep key policymakers informed of state and national level information relevant to energy emergencies.

- Wrote an article on understanding infrastructure security and energy restoration for the widely distributed Northeast-Midwest Economic Review. The publication is distributed to over 3,000 policymakers, government officials, reporters, and others at the federal, state and local level.

Communication and Coordination

- In 2005 during and immediately following the Gulf Coast hurricanes, NASEO communicated with most of the SEOs by convening frequent conference calls between NASEO staff, OE staff and state energy offices and forwarding DOE's Situation Reports as they were received. NASEO worked with a consultant to compile a list of actions taken by states as a result of the hurricanes, including Executive Orders (both draft and final), EPA waiver requests, legislative action, emergency regulations, and official correspondence, ranging from limiting state employee travel to declaring a state of emergency to warning about price gouging.

- In addition, NASEO and its contractor developed and presented a webcast and online training session for EEAC contacts which was attended by approximately 20 SEOs. Presentations were given on the Guidelines, the EEAC network, and ISERnet.

- During the 4th Quarter of 2006, NASEO's contractor worked with DOE and NCSL to present two web casts and online training sessions for EEAC contacts on November 28, 2006 and December 12, 2006.

- NASEO coordinated all of its activities with the National Governors Association (NGA), the National Association of State Regulatory Commissioners (NARUC) and the National Council of State Legislatures (NCSL) by participating in State/Local Government Coordination Meeting conference calls. 


\section{CLEAN ENERGY INTEGRATION}

Promote energy-environment integration pilot efforts in four of the six DOE regions, provide technical assistance, and work collaboratively with EPA, the Environmental Council of States. and other stakeholders to advance various energy-environmental integration initiatives.

- NASEO and Global Environment Technology Fund (GETF) assisted the DOE Regional Offices in defining, promoting, and organizing regional energyenvironment integration pilot projects for the Mid-Atlantic, Southeast, Midwest, and Central Regions. Hosted webcasts on the pilot efforts, conducted Q\&A sessions, and provided advice to states interested in participating in the pilot projects.

- During the 2005-2008 time period, NASEO worked to raise awareness of DOE and EPA energy-environment integration initiatives through:

0 Initiation of a new feature for the NASEO monthly newsletter - The Clean Energy/Environment Corner - featuring stories and articles about states' activities in using EERE measures as cost-effective practices for addressing air quality challenges.

o Sponsored Energy-Environment Integration sessions at the NASEO Annual and Energy Outlook Meetings.

o Worked with the Golden Field Office to ensure that the Air Quality Management Task Force of the Clean Air Act Advisory Committee incorporated substantive recognition of the value of EERE into their deliberations.

o Held meetings with NREL and state energy directors to discuss ways that NREL research and development could be utilized in state energy and air quality programs.

- Collaborated with organizations such as the American Association of State Highway Transportation Officials, Environmental Council of States,

NARUC and the Ozone Transport Commission to identify ways to highlight energy-environment integration initiatives in the states.

- NASEO worked with DOE, EPA, state energy directors, and other clean energy organizations to insure that states were aware of options to receive State Implementation Plan (SIP) credit for EERE measures.

- Consulted with numerous SEOs on addressing energy efficiency and renewable energy issues in the context of air quality problems (e.g., AZ, MO, NY, TX) and identified model programs that could be used in other states.

Global Environment Technology Fund

GETF under contract to NASEO conducted the following activities and accomplishments during the task period.

- Provide technical assistance to states in the energy-environment planning and implementation areas:

o Supported New Jersey efforts on its "Clean Energy and Air Quality Integration Pilot Program" such as review and comment on NJ pilot proposal. 
o Advised State of Virginia of the necessity to establish an avoided emissions rate for use in a set-aside within its implementation of the Clean Air Interstate Rule.

o Developed projects for emissions avoid by the State of Michigan energy efficiency and renewable energy programs for the period 2005-2013.

o Compiled lists of resources and basic outlines of state integration activities in preparation for revitalization of the Energy and Environment Clearinghouse web site.

o Worked with the State of Georgia to create an inventory of current and planned EERE projects.

\section{ENERGY STAR}

Promote DOE Energy Star priorities through outreach and communication with DOE Regional Offices and state organizations; participation in DOE Regional Office meetings with Energy Star staff; coordination of Energy Star information and experiences; and work with DOE HQ and the Regional Offices to showcase models of home performance with Energy Star.

Specific work activities and accomplishments under this task are detailed below:

- NASEO staff created a sub-group of Energy Star states to serve in an advisory capacity. This group worked closely with DOE and the Regional Offices in planning outreach and communication activities such as presentations at NASEO's Annual and Energy Outlook meetings; utilized NASEO's committee structure, particularly the Buildings Committee and the Energy Star Task Force, to expand the reach of Energy Star program activities and information.

- Coordinated the DOE Change-a-light activities for the 2006 campaign. As information on the 2006 campaign became available, NASEO disseminated and coordinated with the SEOs. Information on the photo campaign and general change-a-light information was forwarded to the membership via the NASEO newsletter.

- Updated and released the 2007 and 2008 State Energy Program and Activity Update Booklet at the annual Winter Conferences in Washington, DC in February 2007/08. In addition, NASEO staff made the booklet available on the NASEO web site.

- NASEO staff also created an Energy Star Program Manager database and a one-pager summarizing results from the Energy Star related questions that were included in a 2006 survey that was sent to State Energy Offices.

- Completed case studies focused on successful Energy Star Efforts underway through state and territory energy offices. These case studies were posted to the NASEO website and disseminated through meetings and conferences.

- In support of the DOE Real Estate Initiative, developed a matrix of state activities in Energy Star, Real Estate and Green Building programs. NASEO staff contacted each state and territorial energy office to find out how each of them is promoting energy efficiency in residential buildings and what further support DOE, NASEO and other entities could provide. Reached out to the National Association of Realtors (NAR) in support of the Department of Energy's Real 
Estate Initiatives. Set up meetings among NAR and representatives from California, Delaware, Earth Advantage, and Owens Corning to discuss how state energy offices can work with real estate associations and multiple-listings services to advance residential energy-efficiency information and implementation at the point of sale.

- NASEO, in partnership with Earth Advantage, hosted an interactive webinar on Home Performance with Energy Star on September $25^{\text {th }}, 2008$. The purpose of the web-based event was to provide an overview of the whole-house approach to residential energy efficiency. Speakers included representatives from Austin Energy, NYSERDA, SENTECH, Wisconsin Energy Conservation Corporation, Conservation Services Group, the Energy Trust of Oregon, and the National Home Performance Council. NASEO solicited feedback in developing the webinar from DOE and EPA, as well as other knowledgeable partners in residential energy retrofitting. Over 40 people logged into the event, including state energy officials, NASEO affiliate members and EPA and DOE staff. The webinar had a positive response, with over $85 \%$ of attendees scoring it a 4 or a 5 on a 5 point scale as to their overall satisfaction in a post-event survey.

\section{OFFICE OF ELECTRICITY DELIVERY AND ENERGY RELIABILITY}

Task Title: State Research, Outreach and Technical Assistance to Improve the Nation's Transmission and Distribution System

- Participated in the monthly conference calls of the National Council on Electricity Policy with its partners from NGA, NCSL, and NARUC, conference calls of the Energy, Data and Security Committee, Atlanta TTX exercise planning committee, and quarterly stakeholders meeting.

- Collaborated with DOE as directed under Section 139 of EPAct to conduct a study of state and regional policies that promote cost effective programs for energy efficiency and conservation. Attended the Midwest workshop on Distributed Generation

- Participated in the first leadership group meeting for the DOE Energy Efficiency Action Plan. 


\section{CONCLUSION}

NASEO, through its unique membership (state and territory energy officials from around the country) and collaborative relationship with other state, national, and private energyfocused organizations, has strengthened DOE/state partnership efforts, laying important groundwork for increased cooperative work and opportunities identification for implementation of energy efficiency and renewable energy practices and technologies.

NASEO and its partners through successful provide coordination, outreach, education, training, analysis, and technical assistance in the major task areas of the cooperative agreement has provided states and territories with access to technical information and model approaches that has increased the level of understanding of state energy officials which will enhance the acceleration of energy efficiency and renewable energy programs. 